\title{
Preparation of Optically Active Double-chained Diammonium Cationic Amphiphiles and Their Surface and Colloidal Properties
}

\author{
Shuichi Osanai*, Tomoo Yamamura, Tomomi Okada, and Sadao Yoshikawa \\ Department of Applied Chemistry, Faculty of Science and Technology, Keio University \\ (3-14-1 Hiyoshi, Kohhoku-ku, Yokohama-shi, †223)
}

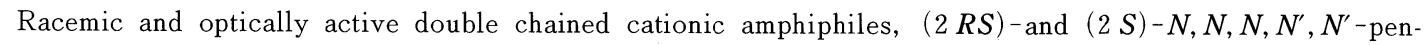
tamethyl- $N^{\prime}$-(2,3-diacyloxypropyl)ethylenediammonium diiodides, were prepared and studied so as to clarify the influence of optical isomerism on surface and colloidal properties, such as surface tension, surface pressure and phase transition temperature.

The morphologies of the aggregates in dilute aqueous solution were investigated by electron microscopy. Well developed multilamella vesicles (MLV) and small unilamella vesicles (SUV) were readily formed from the amphiphiles, depending the conditions of sample preparation.

Phase transition temperature $\left(T_{c}\right)$ of the amphiphile was examined by differential scanning calorimetry. In an amphiphile/water mixed system, optically active sinister homologs showed higher $T_{c}$ than the corresponding racemates, regardless of amphiphile content.

Surface pressure measurements of amphiphiles at the air/water interface indicated the optically active isomers to always have higher surface pressure than the recemate for the same area/molecule.

The properties of aggregate in aqueous solution thus appear to be highly dependent on stereospecific orientation that is influenced by amphiphile chirality.

\section{Introduction}

Since the vesicle forming ability of some kinds of higher dialkyl quaternary ammonium amphiphiles was first recognized, ${ }^{1)}$ numerous reports on the relationship between their structure and aggregating behavior have been progressively published, and in several instances, impressive reactivity controls which is unobtainable in conventional solvents have been realized ${ }^{2)-4}$.

However, there is relatively little literature dealing with the influence of the chirality of the amphiphile upon their physico - chemical properties, such as phase transition temperature $\left(T_{c}\right)$, critical micelle concentration $(\mathrm{cmc})$, surface tension lowering ability, surface pressure when it dispersed on the surface of water ${ }^{5)>8)}$.

Interest in the effects of chirality on the aggregation property has led to the present study. In this study, the amphiphiles, which possessed

Corresponding author : Schuichi OSANAI an asymmetric carbon atom in the middle of the molecule, $N^{\prime}-(2,3$ - diacyloxypropyl) - $N, N$, $N, N^{\prime}, N^{\prime}$ - pentamethyl ethylenediammonium diiodide with acyl chains of $12 \sim 16$ carbons in length (Fig. - 1), were synthesized and the influence of hydrophobic chain length and steric isomerism of molecular on the physico-chemical parameters were evaluated, with a view to more precise characterization of this type of cationic amphiphiles newly synthesized. The objective of much of this research is to develop a systematic approach that would provide a better understanding of the physicochemical properties of the optically active amphiphiles.

\section{Experimental}

\section{$2 \cdot 1$ Analyses and measurements methods}

Melting points were determined on a hotting plate by use of a Yanagimoto melting point apparatus. ${ }^{1} \mathrm{H}$ and ${ }^{13} \mathrm{C}$ NMR spectra were recorded on a JEOL-FX $90 \mathrm{~A}$ spectrometer in a deuterized solvent with TMS as an internal standard, and IR 


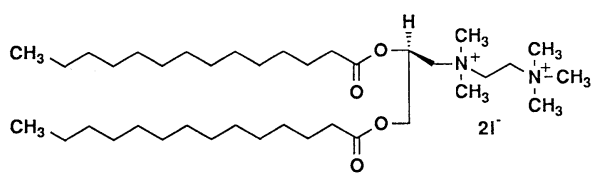

Fig. - 1 Structure of the optically active doublechained cationic amphiphile.

spectra were on JASCO FT/IR 5300. Optical rotations were measured on a JASCO DIP-370 polarimeter.

The water used for the preparation of vesicle dispersion and amphiphiles solution was prepared carefully to remove any colloidal impurities. Deionized water was further distilled by the quartz distilling apparatus. Conductivity and surface tension of the water used were less than $1 \mu \mathrm{S} / \mathrm{cm}$ and more than $71 \mathrm{mN} / \mathrm{m}$, respectively.

Vesicle preparation $^{9), 10)}$ : Dispersions of small unilamellar vesicles (SUV) were prepared as follows. Dried amphiphile $(20 \mathrm{mg})$ were suspended in $2 \mathrm{~mL}$ of water by vortexing for $10 \mathrm{~min}$ at room temperature. The resulted $1 \%$ aqueous dispersion was sonicated for $10 \mathrm{~min}$ in a bath-type sonicator (Bransonic 52 ) at about $10^{\circ} \mathrm{C}$ higher temperature than $T_{c}$.

Transmission electron microscopy (TEM) : A JEOL JEM-2000 FX electron microscope was used at an operating voltage at $80 \mathrm{kV}$. Negatively stained samples were prepared by a standardized technique. Uranyl acetate was used for staining of the amphiphile vesicles. A carbon coated copper grid was employed in all experiments. Standard drop method, that is, a drop of the vesicle solution was applied on to the copper grid, the excess solution blotted off, followed by the addition of a drop of $1 \%$ of the uranyl acetate solution, was used for negative staining. In all procedures, after blotting off the excess of solution from a grid, the grid was left in the air for a few minutes to dry before TEM examination.

Surface tension: Surface tension was measured with a Kyowa Kagaku Co. Model A 3 tensiometer by Wilhelmy's vertical plate method, at $25^{\circ} \mathrm{C}$. The purified amphiphiles were dissolved in water and the surface tensions of didodecanoyl and ditetradecanoyl homologs were measured at various concentration. Dihexadecanoyl homolog was not studied because of its slight solubility in water.

Surface pressure : Surface pressure-molecular occupation area diagram $(\pi-A$ curves $)$ was constructed for the optically active and racemic ditetradecanoyl homologs. The measurements were performed at $30^{\circ} \mathrm{C}$ with a surface pressure meter HBM-A (Kyowa Kagaku Co. ) in a similar manner as described by Abe et al. ${ }^{11)}$.

$\underline{T h e r m a l}^{\text {analysis }}{ }^{12), 13)}$ : Differential scanning calorimetry (DSC) experiments were performed on a Rigaku Thermoflex DSC 8230 apparatus operating at a heating rate of $5{ }^{\circ} \mathrm{C} / \mathrm{min}$. The lipid phase transition temperature $\left(T_{c}\right)$ was defined as the temperature where the slope of an arm of the main peak intersected the baseline in the DSC curve. Preparation of samples for DSC was largely based upon Okahata et al. ${ }^{13)}$. Two different sample preparation methods were available for DSC measurement. In the sonication method, the cationics were suspended in water and subject to ultrasonic treatment with a bath type sonicator to obtain a clear solution. In the freezing method, the sample solutions obtained above were further cooled to $-35^{\circ} \mathrm{C}$ with liquid nitrogen. Sample preparation with the cooling treatment was applied directly in the DSC cell compartment. Heating and cooling of the aluminum pan containing an amphiphilic sample were applied three of four times over crossing the presumed $T_{c}$ to homogenize the mixing state of the greasy sample.

\subsection{Preparation of Amphiphiles}

Racemic and optically active $N^{\prime}-(2,3-$ diacyloxypropyl) - $N, N, N, N^{\prime}, N^{\prime}$ - pentamethyl ethylenediammonium diiodide (10, and $\left.10^{*}\right)$ were prepared according to the following synthetic reaction, shown in Scheme-1.

Raw Materials

The lauroyl (dodecanoyl), myristoyl (tetradecanoyl) and palmitoyl (hexadecanoyl) chlorides were perchased from Tokyo Kasei Chemical Co. (Tokyo), and were used without further purification.

3 -chloro-1,2, $O$-isopropylidene-1,2-propanediol (2) was synthesized in accordance with the method of Newman et al. ${ }^{14)}$. Purified (2) was obtained by the distillation in vacuo, bp. 48 $51^{\circ} \mathrm{C} / 6.0 \mathrm{mmHg} . \mathrm{N}^{\prime}-(2,3-\mathrm{O}$-isopropylidene-2, 3 - dihydroxypropyl) - $N, N$ - dimethyl ethylenediamine (3) was prepared as follows : In an autoclave fitted with a magnetic stirrer, $N, N$ dimethylethylenediamine $(41.8 \mathrm{~g} ; 475 \mathrm{mmol})$ and 


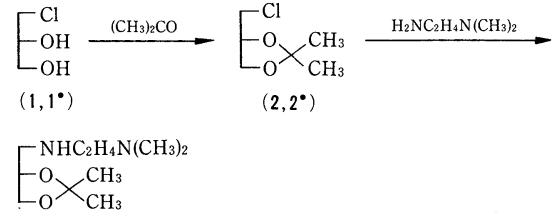

$\left(3,3^{\circ}\right)$
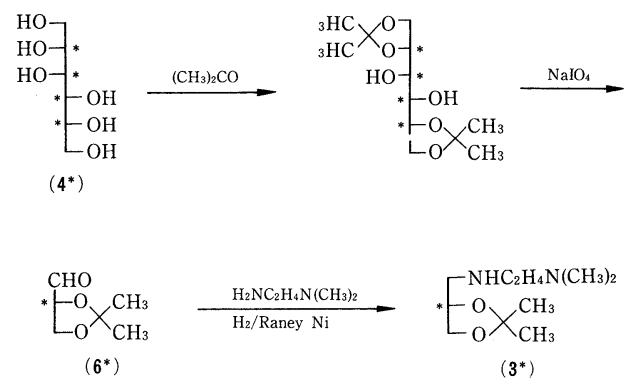

$$
\begin{aligned}
& \left(3,3^{*}\right) \underset{\mathrm{H}_{2} / \text { Raney Ni}}{\mathrm{HCHO}} *\left[-{ }_{\mathrm{O}}^{\mathrm{N}\left(\mathrm{CH}_{3}\right)_{2} \mathrm{H}_{4} \mathrm{~N}\left(\mathrm{CH}_{3}\right)_{2}} \stackrel{\mathrm{H}^{+}}{\mathrm{CH}_{3}}\right. \\
& \left(7,7^{*}\right)
\end{aligned}
$$
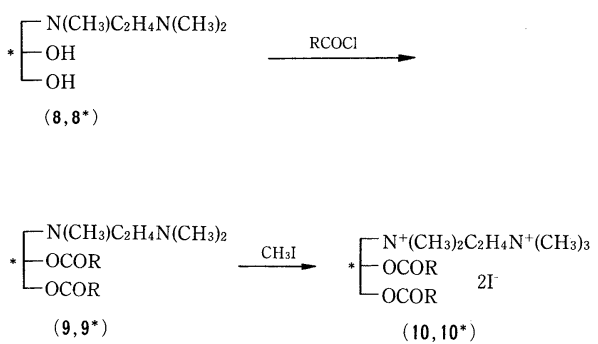

Scheme-1 Preparation of the double-chained cationic amphiphile.

(2) $(28.6 \mathrm{~g} ; 190 \mathrm{mmol})$ were placed. The homogeneous mixture was stirred and heated at $180^{\circ} \mathrm{C}$ for $12 \mathrm{~h}$. After the reaction, excess dimethylethylenediamine was removed in vacuo. The residue was fractionated under reduced pressure to yield colorless liquid (3) $(25.5 \mathrm{~g}$, $66 \%$ yield), bp. $101 \sim 104^{\circ} \mathrm{C} / 5.5 \mathrm{mmHg}$.

The optically active $2,3-O$-isopropylidene$(R)$ - glyceraldehyde $\left(6^{*}\right)$ was prepared by periodate oxidation of 1,$2 ; 5,6$-di- $O$-isopropylidene-D-mannitol $\left(5^{*}\right)^{15)}$, which was available from D-mannitol $\left(4^{*}\right)$ by the method of Chittenden ${ }^{16)}$. $\left(5^{*}\right)$ was purified by the recrystallization from methylenechloride, mp. $117 \sim 121^{\circ} \mathrm{C}$ : lit. ${ }^{16)} 118 \sim 120^{\circ} \mathrm{C}, R_{f}=0.29$ (hexane/AcOEt $=$
$1 / 1(\mathrm{vol} / \mathrm{vol}) .\left(6^{*}\right)$ was distilled in reduced pressure, bp. $52 \sim 53^{\circ} \mathrm{C} / 17 \mathrm{mmHg}$. $[\alpha]_{\mathrm{D}}=+75.5$ $(c=1.07$, Benzene). It was immediately used for next reaction, because of its instability.

The optically active ethylenediamine derivative $\left(3^{*}\right)$ was synthesized by the reductive alkylation of $\mathrm{N}, \mathrm{N}$-dimethylethylenediamine with the optically active isopropylidendated glyceraldehyde $\left(6^{*}\right)$. The intermediate Schiff's base was reduced by $90 \mathrm{~atm}$ of hydrogen at $140^{\circ} \mathrm{C}$ in ethanol using Raney nickel as a catalyst. ( $\left.3^{*}\right)$ was purified by reduced pressure distillation. bp. 113 $\sim 115^{\circ} \mathrm{C} / 7.5 \mathrm{mmHg}, \quad[\alpha]_{\mathrm{D}}=+10.5 \quad(c=1.00$, $28^{\circ} \mathrm{C}$, benzene).

The optical purity of $\left(3^{*}\right)$ was confirmed by comparing the specific rotation of the corresponding isopropylidendated diamine which was prepared from optically active $(2 R)-1$-chloro-2, 3propanediol $\left(\mathbf{1}^{\bullet}\right)$ in the same manner as preparing (3). The specific rotations of two kinds of diamines $\left(3^{*}, 3^{\bullet}\right)$, one was prepared from $\left(1^{\bullet}\right)$ and the other from $\left(6^{*}\right)$ were in fair agreement with each other. These results provided conclusive proof that racemization did not occur during the reductive alkylation from $\left(6^{*}\right)$ to $\left(3^{*}\right)$, therefore, the optical purity of stereo specific amine $\left(3^{*}\right)$ was maintained as high as that of the raw material, $\left(6^{*}\right)$.

Isopropyridendated diamine $\left(3,3^{*}\right)$ were fully $N$-methylated by the reductive methylation with formalin and hydrogen under Raney nickel catalyst. bp. , (7), $102 \sim 105^{\circ} \mathrm{C} / 4.0 \mathrm{mmHg},\left(7^{*}\right)$, $107 \sim 108^{\circ} \mathrm{C} / 5.0 \mathrm{mmHg}, \quad[\alpha]_{\mathrm{D}}=+28.0(c=1.5$, $30^{\circ} \mathrm{C}$, benzene) yield $80.0 \%$. Then, the obtained ditertiary diamine $\left(7,7^{*}\right)$ were deisopropylidendated by a ordinary method through refluxing with $6 \mathrm{~N} \mathrm{AcOH}$, for $2 \mathrm{~h}$.

$N^{\prime}$ - (2,3 - Dihydroxypropyl) - $N, N, N^{\prime}$ trimethyl ethylenediamine, $\left(8,8^{*}\right)$ were acylated as follows : The synthesis of hexadecanoyl homolog is described in detail. All other compounds were prepared under the same conditions. Compound $\left(8,8^{*}\right), 1.73 \mathrm{~g}(9.81 \mathrm{mmol})$, dissolved in a mixed solvent composed of $20 \mathrm{~mL}$ of pyridine and $20 \mathrm{~mL}$ of DMF were placed in a round-bottom flask fitted with a magnetic stirrer, a reflux condenser and a drying calcium chloride tube. Hexadecanoyl chloride, 6.05 g (22.0 $\mathrm{mmol}$ ), in $10 \mathrm{~mL}$ of chloroform was added dropwise at room temperature and the mixture was 
allowed to stand overnight with stirring at room temperature. The reaction solvents were evaporated and the residue was dissolved in $50 \mathrm{~mL}$ ether. Undissolved solids were removed by the centrifuge. The ether phase was washed with saturated brine and water then dried over anhydrous sodium sulfate. The ether phase was concentrated and the residue was fractionated by chromatography on Silica gel (Wakogel 200 mesh) with solvent system of hexane/acetone $=$ $2 / 1$ ( vol/vol). Their $R f$ values $\left(\mathrm{CHCl}_{3} / \mathrm{CH}_{3} \mathrm{OH} /\right.$ $\left.\mathrm{NH}_{4} \mathrm{OH}=90 / 8 / 1\right)$ and specific rotations at $28^{\circ} \mathrm{C}$, [(conc.] in $\left.\mathrm{CHCl}_{3}\right)$ of $\left(9,9^{*}\right)$ containing $\mathrm{C}_{n}$ acyl groups were as follows : $\mathrm{C}_{12}, 0.55,7.1(1.02)$; $\mathrm{C}_{14}, 0.61,7.1$ (1.01); $\mathrm{C}_{16}, 0.65,7.5$ (1.00).

$\left(9,9^{*}\right)$ were quaternarized with methyl iodide. In an autoclave fitted with a magnetic stirrer, 0.7 $\mathrm{g}(1.07 \mathrm{mmol})$ of (9) dissolved in $20 \mathrm{~mL}$ dioxane was placed. After the addition of $0.8 \mathrm{~g}(6.33$ $\mathrm{mmol}$ ) of methyl iodide, the reaction mixture was heated at $45^{\circ} \mathrm{C}$, for $18 \mathrm{~h}$. The solvent and excess methyl iodide were evaporated and the residue purified by the recrystallization from benzene $/$ methanol $=7 / 3(\mathrm{vol} / \mathrm{vol})$.

The structure and purity of each intermediate and end product above-mentioned were established on the basis of their elementary analysis and infrared spectra, proton and carbon nuclear magnetic resonance spectra, in addition to the TLC and physical constants measurements.

The melting points, phase transition temperatures and analytical data of the end product

Table-1 Characteristics of the amphiphiles $\left(10,10^{*}\right)$.

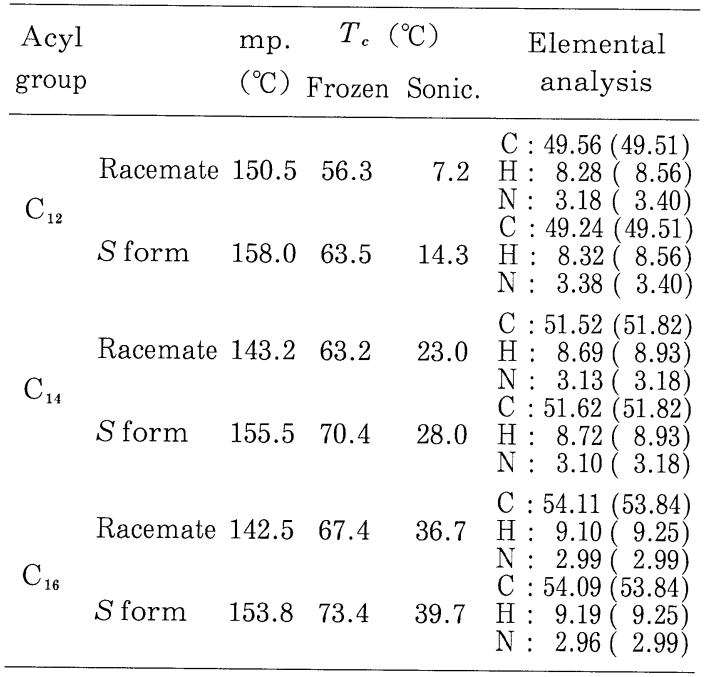

amphiphiles $\left(10,10^{*}\right)$ were summarized in Table1.

\section{Results and Discussions}

\section{Electron Microscopies}

Fig. - 2 shows representative TEM of the differently aggregated amphiphile preparations. As shown in Fig.-2 A, B TEM observations revealed that these amphiphiles readily formed stable small unilamellar vesicle (SUV) regardless of their optical isomerism and acyl chain length in the range of $\mathrm{C}_{12}$ to $\mathrm{C}_{16}$. The images of the SUV were seen as spherical of about $30 \sim 80$ $\mathrm{nm}$ in diameter. These particle sizes were very similar to those found for dihexadecanoylphosphatidylcholine vesicles prepared by $\mathrm{Lukac}^{17)}$. However, in the case of short time sonication for the aggregate preparation, the sinister amphiphile tended to produce multilamella vesicles (MLV) (Fig.-2 C, D). There were so many opportunities to observe multi-walled vesicles and lamellae in one specimen. Both MLV and SUV were generally coexisted at equilibrium at the same time. The thickness per each layer, regardless of multi-walled and single-walled vesicles, was estimated to be $4 \sim 6 \mathrm{~nm}$, approximately twice the length of the hydrophobic segment of the amphiphiles, it was consistent with those of another type of amphiphiles involving amino acid and choline residues ${ }^{177,18)}$. In terms of chirality of the amphiphilic cationics only a slight influence was recognized on the size of vesicles and the thickness of bilayer.

Surface tension of aqueous solution

The profiles of surface tension $v s$. concentration of the racemic and optically active amphiphiles possessing two tetradecanoyl groups are shown in Fig. -3 and their $\mathrm{cmc}$ and $\gamma_{c m c}$ are summarized in Table-2.

The formation of micelles was confirmed by the breaking point in Fig.-3. The $\mathrm{cmc}$ of the racemic compounds was larger than that of the optically active isomer. On the other hand, there were slight differences in surface tension lowering ability among the optical isomers of the diacyl diammonium cationic amphiphiles. Since each amphiphile studied here contains two lipophilic acyl groups and two hydrophilic quaternary ammonium residues in one molecule, it would possess a similar HLB value to that of a ordinary 

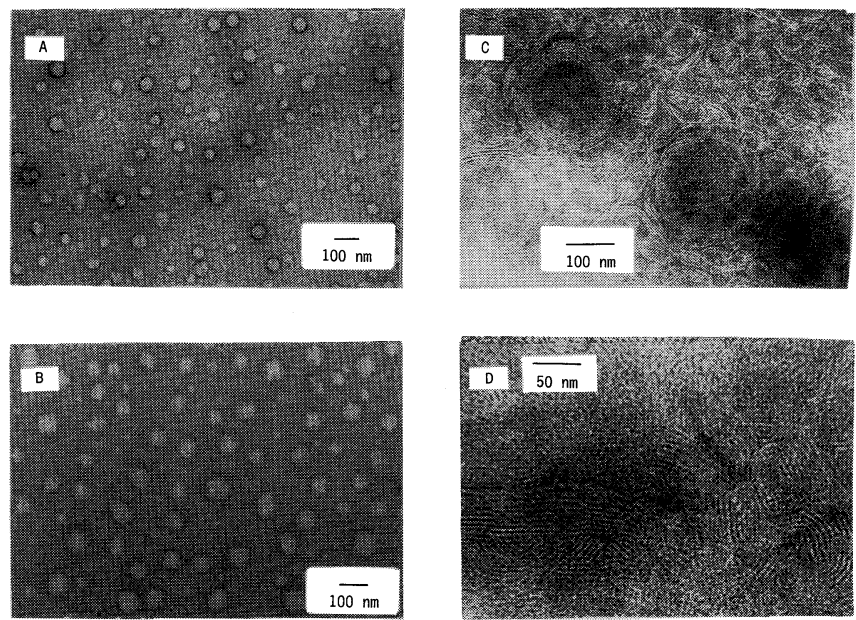

A : SUV, $r a c^{-} \mathrm{C}_{14}, \mathrm{~B}$ : SUV, $r a c^{-} \mathrm{C}_{16}, \mathrm{C}$ : MLV, $S-\mathrm{C}_{14}$, D : Lamellae, rac- $\mathrm{C}_{12}$.

Fig.-2 TEM of amphiphile vesicles and lamellae stained with uranyl acetate by using the drop method.

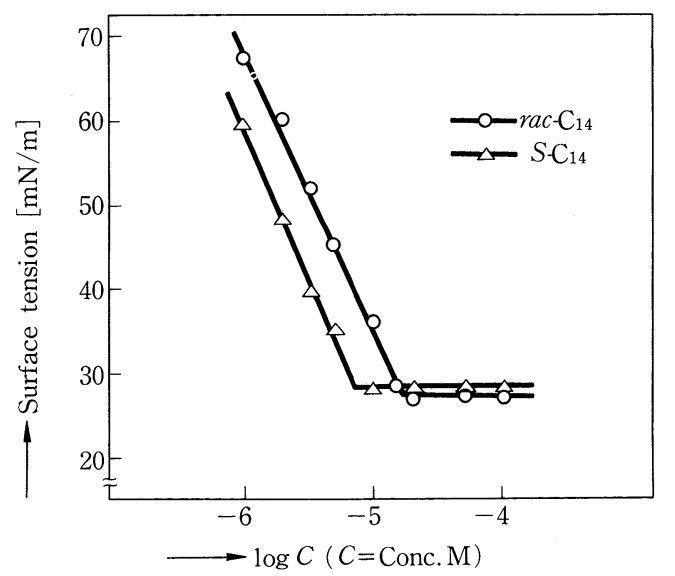

Fig.-3 Surface tension-concentration curves of the amphiphiles. (10, 10*)

quaternary ammonium cationics containing a single hydrophobic and a hydrophilic group, like a tetradecyltrimethylammonium chloride (TTAC ${ }^{19)}$. In spite of these estimates, the amphiphiles showed considerably lower $\mathrm{cmc}$ values and pronounced surface tension lowering ability than the ordinary cationics like a TTAC, which do not form stable bilayer assemblies ${ }^{20)}$. Even if the fact that the molecular weight of the amphiphile under investigation is about twice that of TTAC, would be considered, cmc of the double chained cationics was significantly small.

A sturdy and huge hydrophobic group, com-
Table-2 Surface tension and $\mathrm{cmc}$ of the amphiphiles.

\begin{tabular}{|c|c|c|c|c|}
\hline & $\begin{array}{c}\text { Dodecar } \\
\gamma_{\mathrm{cmc}} \\
(\mathrm{mN} / \mathrm{m})\end{array}$ & $\begin{array}{l}\text { cmc }\left(\mathrm{C}_{12}\right) \\
\text { (M) }\end{array}$ & $\begin{array}{c}\text { Tetradec } \\
\gamma_{\mathrm{cmc}} \\
(\mathrm{mN} / \mathrm{m})\end{array}$ & $\begin{array}{c}\text { anoyl }\left(\mathrm{C}_{14}\right) \\
\mathrm{cmc} \\
(\mathrm{M})\end{array}$ \\
\hline Racemic & 29.8 & $1.7 \times 10^{-5}$ & 28.0 & $1.8 \times 10^{-5}$ \\
\hline Sinister & 29.3 & $1.0 \times 10^{-5}$ & 27.5 & $0.76 \times 10^{-5}$ \\
\hline
\end{tabular}

posed of the two higher acyl groups, combined by the steady covalent bond may promote amphiphile molecules to aggregate and to orient at air/water interface. The cmc values for the amphiphiles are also comparable to those for another ammonium type and peptide type amphiphiles containing double lipophilic groups ${ }^{18), 19)}$.

Stereospecific regularity of the hydrophobic group, and the ethylenediammonium hydrophilic substituent at asymmetric carbon greatly affected the cmc. Higher regularity enhanced the aggregating tendency of the amphiphile and stablized the aggregates at more dilute concentration. This difference between cmc values of the two kinds of stereoisomers may be ascribable to the different contribution of the stereospecific arrangement at the surface of the aggregates.

Surface pressure at air/water interface

Fig. -4 illustrates the $\pi-A$ isotherms for the racemic and optically active amphiphiles, and shows the importance of the steric configuration 
of the amphiphiles. within the steric isomers containing same two tetradecanoyl groups, two kinds of stereoisomer produced different, though not basically dissimilar $\pi$ - $A$ curves. The optically active isomer always showed lower surface pressure than racemate at the same area/molecule, namely curve sinister lay on a smaller area side and hence its packing density of the monolayer was slightly larger than that of racemate. The molecular areas were 81.7 for the sinister and $93.0 \AA^{2} /$ molecule for the racemate, respectively.

In analogy with the information obtained in the surface tension measurements, it showed that, the optical activity of the amphiphile affected the orientation of the monolayer at the air/water interface.

Thermal analysis by DSC (mp. and $T_{c}$ )

It is clear by looking at Table-1 that the melting points $(\mathrm{mp})$ and phase transition temperatures $\left(T_{c}\right)$ of the optically active amphiphiles were higher those of the corresponding racemates.

Thermal analysis of the aqueous bilayer dispersion system was studied over the concentration range $0.95>c>0.01$ and the temperature range $-30^{\circ} \mathrm{C}<T<90^{\circ} \mathrm{C}$. The representative DSC heating curves for the racemates containing a different acyl group are shown in Fig. -5 .

The endothermic peak corresponding to their $T_{c}$ shifted to higher temperature as the number of

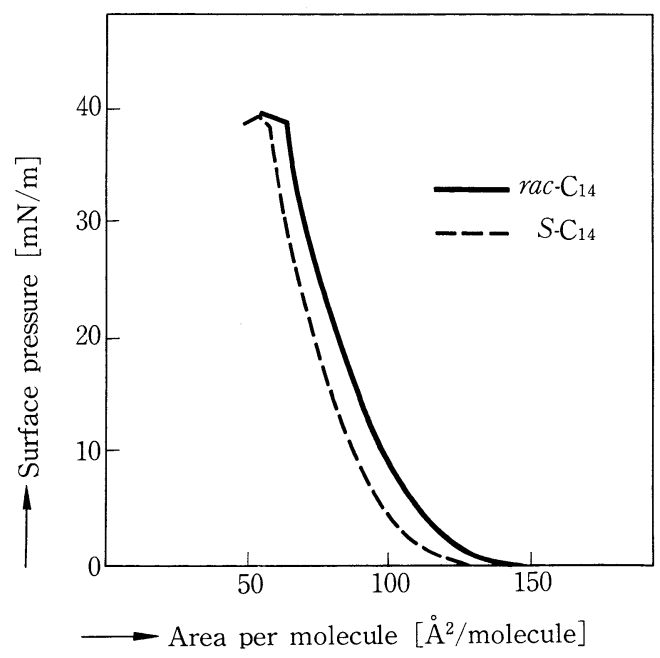

Fig. -4 Surface pressure-area $(\pi-A)$ curves of the amphiphiles. carbon of acyl chain length increased.

The variation of $T_{c}$ under various amphiphile concentration are shown in Fig.-6. Addition of water resulted in a lowering of $T_{c}$. For the ditetradecanoyl homolog, $T_{c}$ decreased steadily as an appreciable amount of water added, and reached a limiting value of $63.2^{\circ} \mathrm{C}$ for the racemate and $70.4^{\circ} \mathrm{C}$ for the sinister. Their $T_{c}$ remained constant on an addition of further water. The constant temperature like this was defined as $T_{c}$ and summarized in Table-1. $T_{c}$ values of the optically active amphiphiles were always $3 \sim 7$ degrees higher than that of the racemates. As mentioned previously, this behavior could be assumed to be caused by some differences of packing and orientation in the aggregates. The differences of $T_{c}$ between stereoisomers decreased as the number of carbon atoms of acyl group increased.

In spite of the existence of an appreciable amount of water in the amphiphile/water system, the peak due to the fusion of ice at $0^{\circ} \mathrm{C}$ was not observed in the region under $19 \%$ by weight of water (Fig. -7 ). A ratio of the amphiphile to the

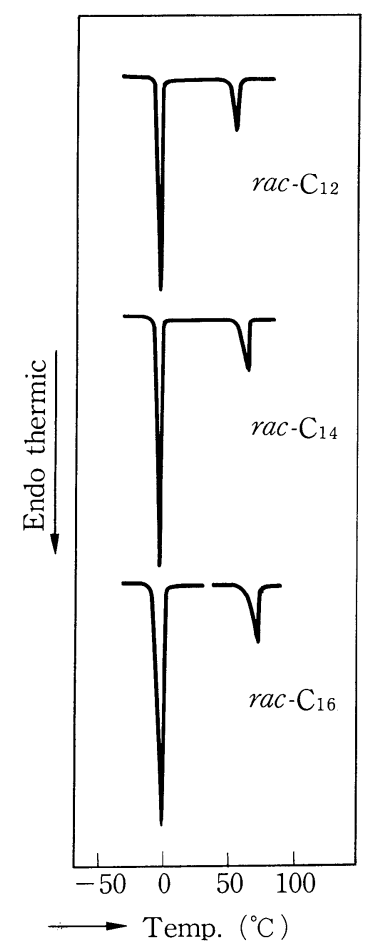

Fig. -5 DSC curves of the aqueous amphiphile bilayers prepared by the freezing method at $c=0.5$. 


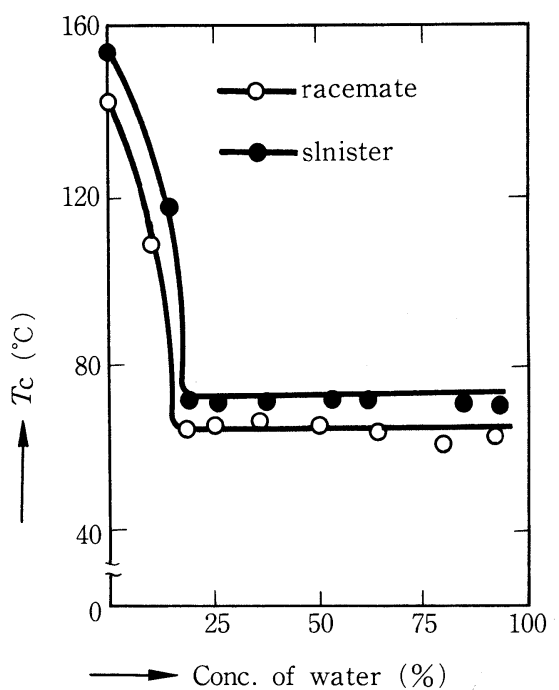

Fig.-6 Variation of $T_{c}$ with water concentration in amphiphile/water system.

bound water was about $1: 4$ by weight, that is, one amphiphilic molecule associated with 10 water molecules, which did not form an ice on cooling even to $-30^{\circ} \mathrm{C}$.

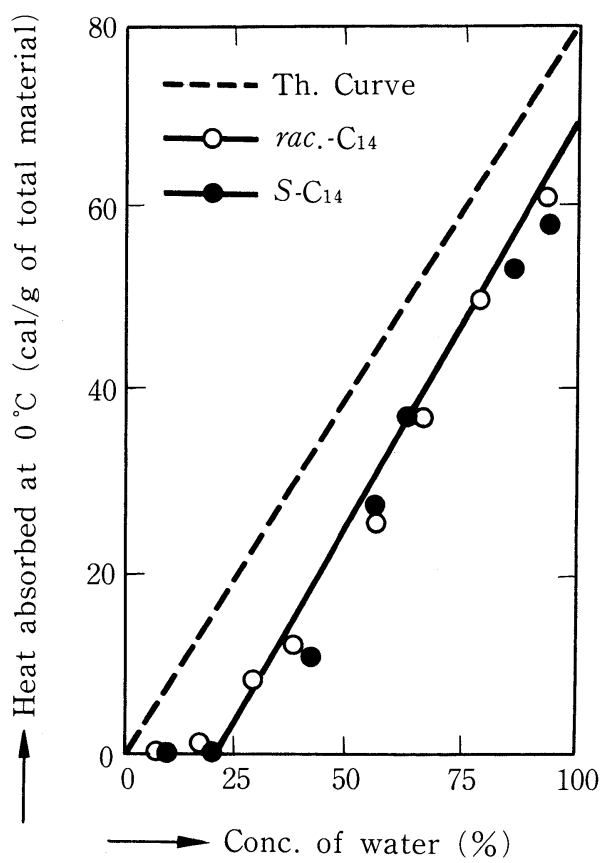

Dotted line is a theoretical curve assuming that no water bound to the amphiphile.

Fig. -7 Variation of heat absorbed at $0^{\circ} \mathrm{C}$ with water concentration for $\mathrm{C}_{14}$ amphiphiles.
In addition to the relationship between the chain length of acyl group and $T_{c}$, another particular features in DSC analysis were observed for sonicated and frozen samples of aqueous dispersions. $T_{c}$ of the amphiphiles was greatly affected by the sample preparation. The samples prepared by the frozen method showed higher $T_{c}$ values than those for the corresponding sonicated samples by $30 \sim 49^{\circ} \mathrm{C}$. These findings suggested that considerable reorganization of the aggregated molecules was induced during the freezing process by water located among the amphiphile layer.

The authors wish to thank Prof. K. Ogino, Dr. M. Abe, Science University of Tokyo, for their advice with surface pressure measurements and to appreciate the help received from Dr. T. Fujiwara, Electron microscope Laboratory, Keio Univ. with TEM observation.

(Received July 18, 1991)

\section{References}

1) T. Kunitake and Y. Okahata, J. Am. Chem. Soc., 99, 3860 (1977).

2) T. Kunitake, N. Kimizuka, N. Higashi, and N. Nakashima, J. Am. Chem. Soc., 106, 1978 (1984).

3) T. J. Racey, M.A. Singer, L. Finegold, and P. Rocchon, Chem. Phys. Lipids, 49, 271 (1989).

4) J.W. Verbickey, Jr. and E. A. O'Neil, J. Org. Chem., 50, 1786 (1985).

5) K. Yamauchi, F. Une, S. Tabata, and M. Kinoshita, J. Chem. Soc., Perkin Trans. I, 1986, 765 .

6) M. Takehara, I. Yoshimura, and R. Yoshida, J. Am. Oil Chem. Soc., 51, 419 (1974).

7) S. Osanai, S. Yuhara, and Y. Abe, Yukagaku, 33, 372 (1984).

8) S. Osanai, Y. Yoshida, K. Fukushima, and S. Yoshikawa, J. Jpn. Oil Chem. Soc. (YUKAGA$K U), 38,633$ (1989).

9) J. Sunamoto, K. Iwamoto, K. Inoue, T. Endo, and S. Nojima, Biochim. Biophys. Acta, 685, 283 (1982).

10) B. De Kruyff, P.W.M. Van Dijck, R.A. Demel, A. Schuijff, F. Brants, and L.L.M. Van Deenen, Biochim. Biophy. Acta, 356, 1 (1974).

11) K. Ogino, M. Goto, and M. Abe, J. Jpn. Oil Chem. Soc. (YUKAGAKU), 37 (8), 640 (1988).

12) D. Chapman, R.M. Williams, and B.D. Ladbrooke, Chem. Phys. Lipids, 1, 445 (1967).

13) Y. Okahata, R. Ando, and T. Kunitake, Ber. Bunsenges. Phys. Chem. 85, 789 (1981). 
14) M.S. Newmann and M. Renoll, J. Am. Chem. Soc. , 67, 1621 (1945).

15) D.Y. Jackson, Synth. Commun., 18(4). 337 (1988)

16) G. J.F. Chittenden, Carbohydr. Res., 84, 350 (1980).

17) S. Lukac and A. Perovic, J. Colloid Interface Sci., 103, 586 (1985).

18) Y. Murakami, A. Nakano, and H. Ikeda, $J$. Org. Chem., 47, 2137 (1982).

19) J.H. Fendler and E. J. Fendler, 'Catalysis in Micellar and Macromolecular System: Academic Press, New York, (1975) Table 2-1.

20) T. Kunitake, Y. Okahata, R. Ando, S. Shinkai, and S. Hirakawa, J. Am. Chem. Soc., 102, 7877 (1980).

\section{光学活性な 2 鎖型ジアンモニウム \\ カチオン両親媒化合物の合成及び \\ それらの界面化学的性質}

小山内州一 - 山村朝雄 - 岡田知巳 - 吉川貞雄

慶應義塾大学理工学部（†223 横浜市港北区日吉 3-14-1)

光学活性及びラセミ体の 2 鎖型カチオン両親媒化合 物, (2RS) - , (2S) - $N^{\prime}-(2,3$ - diacyloxy propyl) $N, N, N, N^{\prime}, N^{\prime}$-pentamethyl ethylenediammonium diiodide, を合成し, これらの化合物の表面張力, 表面 圧，転移温度等の集合挙動が光学異性によってどのよう な影響を受けるか検討した。透過型電子顕微鏡により水 溶液中でのモルフォロジーを観察し, MLVや SMVが それらの試料調製法によって生じることが認められた。 DSCによる $T_{c}$ の測定結果, 光学活性体がより高い $T_{c}$ を示すことが認められた。また表面圧測定において，光 学活性体が同一な面積/分子値において高い表面圧を示 した。

これらの結果は，両親媒化合物が水中にて集合する際 にそのキラリティが配向を制御し上に述べた差異が生じ たものと考えられる。

連絡者：小山内州一 